\title{
Tide as Steering Factor in Structuring Archaeal and Bacterial Ammonia-Oxidizing Communities in Mangrove Forest Soils Dominated by Avicennia germinans and Rhizophora mangle
}

\author{
Magalí S. Marcos ${ }^{1,2}$ • Anthony D. Barboza ${ }^{1,3}$ • Rosalinde M. Keijzer ${ }^{1}$. \\ Hendrikus J. Laanbroek ${ }^{1,4}$
}

Received: 21 September 2017 / Accepted: 7 October 2017 /Published online: 23 October 2017

(C) The Author(s) 2017. This article is an open access publication

\begin{abstract}
Mangrove species are adapted to grow at specific zones in a tidal gradient. Here we tested the hypothesis that the archaeal and bacterial ammonia-oxidizing microbial communities differ in soils dominated by the mangrove species Avicennia germinans and Rhizophora mangle. Two of the sampling locations were tidal locations, while the other location was impounded. Differences in the community compositions of ammonia-oxidizing archaea (AOA) and bacteria (AOB) were analyzed by denaturing gradient gel electrophoresis (DGGE) of amoA genes and by MiSeq 16S rRNA genesequencing. The abundances of $\mathrm{AOA}$ and $\mathrm{AOB}$ were established by quantitative PCR of amoA genes. In addition, we analyzed the total microbial community composition based on 16S rRNA genes and explored the influence of soil physicochemical properties underneath Avicennia germinans and Rhizophora mangle on microbial communities. AOA were always more abundant than AOB, but the effect of mangrove species on total numbers of ammonia oxidizers was
\end{abstract}

Electronic supplementary material The online version of this article (https://doi.org/10.1007/s00248-017-1091-y) contains supplementary material, which is available to authorized users.

Hendrikus J. Laanbroek

r.laanbroek@nioo.knaw.nl

1 Department of Microbial Ecology, Netherlands Institute of Ecology (NIOO-KNAW), P.O. Box 506700 AB Wageningen, the Netherlands

2 Laboratorio de Microbiología y Biotecnología, Instituto Patagónico para el Estudio de los Ecosistemas Continentales (IPEEC, CONICET), Puerto Madryn, Argentina

3 Centro Interdisciplinar de Pesquisas em Biotecnologia - CIP-Biotec, Universidade Federal do Pampa, Campus São Gabriel, São Gabriel, Brazil

4 Ecology and Biodiversity Group, Department of Biology, Utrecht University, Utrecht, the Netherlands location-specific. The microbial communities including the ammonia oxidizers in soils associated with $A$. germinans and $R$. mangle differed only at the tidal locations. In conclusion, potential site-specific effects of mangrove species on soil microbial communities including those of the AOA and AOB are apparently overruled by the absence or presence of tide.

Keywords AOA $\cdot$ AOB $\cdot$ Microbial community structure $\cdot$ Mangroves $\cdot$ Avicennia germinans $\cdot$ Rhizophora mangle

\section{Introduction}

Mangrove forests are highly valuable ecosystems for the numerous products and fundamental services they provide [1]. These ecosystems are confined to intertidal coastal areas from (sub)tropical regions, and within these areas they often show zonation patterns, in which monospecific bands of trees are formed parallel to the shoreline [2]. In Florida, Rhizophora mangle usually occurs lower in the intertidal zone than Avicennia germinans that can be found more at in-land sites where tidal inundation is less frequent [3]. Species of the genera Rhizophora and Avicennia, which are among the most widely distributed mangroves of the world [4], differ in their potential for growth, resource acquisition, stress tolerance, and susceptibility to herbivores [5]. Avicennia and Rhizophora also differ in their adaptations to live under flooded conditions. One of these adaptations concerns their root systems through which they influence the biogeochemistry of the soil. Distinct differences in soil $\mathrm{pH}$ values, redox potentials, sulfide, and organic matter concentrations were reported in soils covered with these mangrove trees [6]. In addition, these species differ in their tissue chemistry: Rhizophora spp. have higher contents of total soluble phenolics (including tannins) and higher $\mathrm{C}: \mathrm{N}$ ratios (i.e., lower nutritive value) than 
Avicennia spp. [5, 7]. These attributes may in turn be associated with the generally slower rates of organic matter decomposition of Rhizophora tissues [8].

Ammonia-oxidizing archaea (AOA) of the Thaumarchaeota and ammonia-oxidizing bacteria $(\mathrm{AOB})$ of the $\beta$ - and $\gamma$ Proteobacteria are critical players in the global nitrogen cycle, because they perform the first and often rate-limiting step of nitrification under oxic conditions - i.e., the oxidation of ammonia to nitrite [9, 10]. Since the enzyme ammonia monooxygenase catalyzes this first step in aerobic ammonia oxidation, the amoA gene encoding the $\alpha$ subunit of this enzyme has been frequently used as molecular marker in ecological studies of these microorganisms [11]. Culture-independent studies based on amoA and on 16S rRNA genes demonstrated a ubiquitous distribution of $\mathrm{AOB}$ and $\mathrm{AOA}$ in a variety of environments (even extreme habitats) [12], in which their relative abundance and community composition may be determined not only by one factor but by a combination of several environmental characteristics [13]. However, in spite of their widespread distribution, it was only recently that studies focused on AOA and AOB from mangrove ecosystems, and on the environmental factors that determine their abundance and community composition [14-21].

Mangrove trees can have different impacts on soil archaeal and bacterial communities through alteration of the soil microenvironment such as changes in the content of organic matter or other sediment characteristics [22, 23], root exudates [24, 25], and litter inputs [26]. Moreover, recent studies suggested that mangrove plants could be important factors controlling the activity, abundance, and community structure of ammonia oxidizers [14, 15, 18]. Laanbroek et al. observed that three A. germinans habitats from Florida that differed in tree height and density of canopy cover also differed in their AOB community composition, suggesting that the environmental factors that control the growth and coverage of A. germinans also affect the community composition of AOB [14]. In mangroves from China, the mangrove Kandelia obovata promoted higher nitrification rates, and higher abundance of bacterial amoA genes and archaeal amoA transcripts compared to bare sediments [18]. In this study, numbers of archaeal amoA genes and transcripts always exceeded those of their bacterial equivalents. Higher abundances of bacterial than archaeal amoA genes and transcripts were also detected in mangrove sediments from Mai Po Nature Reserve (Hong Kong), and in sediment microcosms amended with ammonium and nitrite, suggesting important roles for $\mathrm{AOB}$ in these mangrove ecosystems [16, 20]. However, archaeal amoA genes were more abundant than their bacterial counterparts in sediments from Florida covered with A. germinans [15], and in polluted Chinese mangrove sediments covered with $K$. obovata [19].

Based on the effects of mangrove species on microbial communities as described above, we hypothesized that the archaeal and bacterial ammonia-oxidizing communities in the root zones of Avicennia and Rhizophora species differ. We tested this hypothesis on soil samples collected from below A. germinans or $R$. mangle soil at the coast of Florida. Since former studies on ammonia-oxidizing archaea and bacteria were restricted to impounded A. germinans forests at the east coast with a restricted tidal regime $[14,15]$, we extended the sampling to tidal sites dominated by either A. germinans or R. mangle. We looked for differences in the ammoniaoxidizing communities by denaturing gradient gel electrophoresis (DGGE) of amoA genes and by MiSeq 16S rRNA genesequencing. We established also the abundance of AOA and AOB by means of quantitative amplification of $a m o A$ genes in the soils. Since the MiSeq 16S rRNA yielded also information on the diversity of the total archaeal and bacterial communities, we evaluated the diversity and composition of these communities as well. Furthermore, we explored the influence of physicochemical properties of the soils dominated by A. germinans and $R$. mangle on the total microbial communities based on $16 \mathrm{~S}$ rRNA patterns.

\section{Materials and Methods}

\section{Site Description and Soil Sampling}

Soil sampling was performed at three locations at the coast of Florida. One sampling site was located on the western coast, at

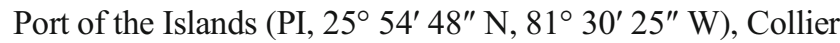
County. The other two sampling sites were on the western shores of a series of barrier islands located on the eastern coast of Florida; one of them at South Hutchinson Island (SHI, $27^{\circ}$ $\left.17^{\prime} 00^{\prime \prime} \mathrm{N}, 80^{\circ} 13^{\prime} 00^{\prime \prime} \mathrm{W}\right)$, Martin County, and the other at

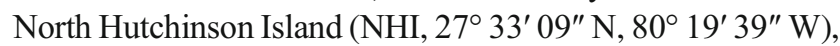
in St. Lucie County. PI is a resort and marina at the Ten Thousand Islands National Islands Refuge, and an important habitat and refuge for aquatic life, including manatees [27]. SHI and NHI are part of the barrier islands that separate the Indian River Lagoon from the Atlantic Ocean. Some of the mangrove sites in this lagoon among which the sampling location at NHI, have been impounded to control noxious mosquitoes and midges [14]. Therefore, NHI has limited tidal exchange, whereas both SHI and PI are tidal locations. Further information on the sampling sites can be found in [28, 29]. At each location, four soil samples were collected from a site dominated by $A$. germinans and four samples from a site dominated by $R$. mangle, all near the roots of the trees, totalizing 24 samples ( 3 locations $\times 2$ mangrove species $\times 4$ replicates). The mutual distance between the samples at the site of one species was a few meters at the most. Upper $5-\mathrm{cm}$ soil samples were collected using cores of 2-cm diameter, cooled and freeze-dried upon arrival in the laboratory for molecular analyses. At the sampling locations, additional upper 
5-cm soil samples were collected for physical and chemical analyses of the soil [28]. Sample names were chosen according to the sampling site (PI, Port of the Islands; SHI, South Hutchinson Island; NHI, North Hutchinson Island), followed by the mangrove species (A, A. germinans; R, R. mangle), and the number of replicate (1-4).

\section{Characterization of Mangrove Soils}

The concentrations of sulfur compounds and heavy metals in soil samples were determined by the Flemish Institute for Technological Research (VITO) in Belgium. Further metadata of these soil samples, including particle size, total organic carbon (TOC), $\mathrm{pH}$, salinity, nitrate, and nitrite concentrations, have been previously described [28].

\section{Metagenomic DNA Extraction}

Metagenomic DNA was purified from ca. $0.3 \mathrm{~g}$ of freeze-dried soil samples using the Maxwell@ 16 Tissue DNA Purification Kit and Instrument (Promega Corporation, Madison, WI, USA), following the manufacturer's instructions. DNA concentration and purity were measured with a NanoDrop 2000 Spectrophotometer (Thermo Fisher Scientific, Waltham, MA, USA). Further, DNA concentrations were determined using the QuantiFluor ${ }^{\circledR}$ dsDNA System (Promega Corporation, Madison, WI, USA), to corroborate the quantifications obtained using the NanoDrop.

\section{AOA and AOB Community Composition}

The amplification of the amoA genes for DGGE was performed by nested PCR. The first PCR of the bacterial amoA genes was conducted using the $a m o A-1 \mathrm{~F} / a m o A-2 \mathrm{R}$ primer set [30] and the amplification conditions from Table 1, whereas that for the amoA genes of AOA was conducted using the Arch-amoAF/Arch-amoAR primers [11]. Then, a second PCR was performed using these PCR products as template DNA, the same primer sets as in the first round but with a GC clamp in the reverse primer, and the amplification conditions described in Table 1. PCR reactions contained $1 \times$ Green GoTaq ${ }^{\circledR}$ Flexi Buffer (Promega Corporation, Madison, WI, USA), $1 \mathrm{mM} \mathrm{MgCl}, 0.4 \mathrm{mM}$ dNTPs, $0.2 \mu \mathrm{M}$ of each primer, 1.25 U GoTaq® G2 Hot Start Polymerase, 1-1.5 $\mu$ l template DNA, and ultrapure water. Control reactions without DNA, as well as positive controls, were included in all runs. PCR products were analyzed by electrophoresis in $1.5 \%$ agarose gels to confirm the presence of bands of the specific size.

PCR products were loaded in $6 \%$ polyacrylamide gels with $20-55 \%$ and $35-60 \%$ denaturing gradients for archaeal and bacterial genes, respectively (where $100 \%$ denaturant was $7 \mathrm{M}$ urea and $40 \%$ formamide in $0.5 \times$ TAE buffer). Electrophoresis was carried in a PROTEAN® II xi Cell (Bio-
Rad Laboratories, Hercules, CA, USA) using $0.5 \times$ TAE buffer. Gels were run at $60^{\circ} \mathrm{C}$, during $17 \mathrm{~h}$ at $100 \mathrm{~V}$ (AOA) or $12 \mathrm{~h}$ at $80 \mathrm{~V}$ (AOB), and then stained with ethidium bromide and visualized in a transilluminator. The banding pattern of DGGE was compared among samples using the Image master 1D Database Software.

\section{Quantification of amoA Genes from $\mathrm{AOA}$ and $\mathrm{AOB}$}

Real-time PCR assays to quantify the bacterial and archaeal $a m o A$ genes in soil samples were performed in a RotorGene ${ }^{\circledR}$ Q thermocycler (QIAGEN, Hilden, Germany), using the primers and amplification programs described in Table 1. All reactions contained $1 \times$ SYBR $\AA$ Green Master Mix (Bio-Rad Laboratories, Hercules, CA, USA), $5 \mu \mathrm{g} \mathrm{ml}^{-1}$ BSA, $250 \mathrm{nM}$ of each primer, 1:40-1:4 dilution template DNA (depending on the presence of inhibitors and the abundance of the target gene in each DNA sample), and ultrapure water. Control reactions, where template DNA was replaced by ultrapure water, were included in all runs. Melting curves were run at the end of the program to verify the specificity of the amplified products. Standard curves were constructed by performing 1:10 serial dilutions of amoA genes amplified from uncultured $\mathrm{AOB}$ and $\mathrm{AOA}$, in the ranges of $5-10^{7}\left(r^{2}>0.98\right)$ and $10^{2}-10^{9}$ $\left(r^{2}>0.99\right)$ for bacterial and archaeal genes, respectively.

\section{Microbial Community Structure and Diversity}

Bacterial and archaeal 16S rRNA genes of the 24 soil DNA samples were amplified and sequenced at BGI (Copenhagen, Denmark). The 515F/806R primer set [34] was used to amplify the V4 hypervariable region of $16 \mathrm{~S}$ rRNA genes from both Bacteria and Archaea. Paired-end sequencing was performed using an Illumina MiSeq Sequencing platform. Sequences were processed using the software QIIME v 1.9.1 [35]. Briefly, forward and reverse sequences were joined, demultiplexed, and filtered according to quality scores $(<25$ were removed), chimeric sequences, and read length ( $<200$ bp were removed). Five of the 24 DNA samples (NHI-A2, NHI-R3, PI-A1, PI-R1, and PI-R2) produced less than 500 reads, and therefore were discarded from further analyses. After filtering steps, we had a total of 117,649 reads from 19 samples (minimum: 966, maximum: 14,506 reads per sample). Sequences were aligned using the SILVA database v 128 as template [36]. Operational taxonomic units (OTUs) were picked at $97 \%$ sequence similarity using UCLUST, and taxonomy was assigned using the SILVA database v 128 [36].

The Good's coverage index was calculated for each soil sample, as a measure of the depth of sequencing effort. Alpha diversity metrics (total observed OTUs, Simpson evenness $(1 / \mathrm{D} / \mathrm{S})$, and the Shannon index $\left(\mathrm{H}^{\prime}\right)$ as richness, 
Table 1 Primers and programs used to amplify the $a m o A$ genes of ammonia-oxidizing archaea (AOA) and bacteria (AOB)

\begin{tabular}{|c|c|c|c|c|}
\hline Primers & Target & Use & Amplification program & Reference \\
\hline amoA-1F/amoA-2R & AOB $\beta$-Proteobacteria & qPCR, first PCR for DGGE & $\begin{array}{l}5 \mathrm{~min} \text { at } 95^{\circ} \mathrm{C} \text {, followed by } 45 \text { cycles } \\
\text { of } 20 \mathrm{~s} \text { at } 95^{\circ} \mathrm{C}, 20 \mathrm{~s} \text { at } 59{ }^{\circ} \mathrm{C}, 20 \mathrm{~s} \\
\text { at } 72{ }^{\circ} \mathrm{C} \text {, and a final step of } 15 \mathrm{~s} \text { at } \\
82{ }^{\circ} \mathrm{C} \text { before fluorescence read }\end{array}$ & {$[30]$} \\
\hline $\begin{array}{l}\text { Arch-amoAF/AOA_amoA } \\
\text { 175Brev }\end{array}$ & $\mathrm{AOA}$ & qPCR & $\begin{array}{l}5 \mathrm{~min} \text { at } 95^{\circ} \mathrm{C} \text {, followed by } 45 \text { cycles } \\
\text { of } 20 \mathrm{~s} \text { at } 95^{\circ} \mathrm{C}, 30 \mathrm{~s} \text { at } 58{ }^{\circ} \mathrm{C}, 30 \mathrm{~s} \\
\text { at } 72{ }^{\circ} \mathrm{C} \text {, and a final step of } 15 \mathrm{~s} \text { at } \\
82{ }^{\circ} \mathrm{C} \text { before fluorescence read }\end{array}$ & {$[11,31]$} \\
\hline Arch-amoAF/Arch-amoAR & $\mathrm{AOA}$ & First PCR for DGGE & $\begin{array}{l}10 \text { min at } 95^{\circ} \mathrm{C} \text {, followed by } 45 \text { cycles } \\
\text { of } 15 \mathrm{~s} \text { at } 95^{\circ} \mathrm{C}, 45 \mathrm{~s} \text { at } 56^{\circ} \mathrm{C} \text { and } \\
45 \mathrm{~s} \text { at } 72^{\circ} \mathrm{C}\end{array}$ & {$[11]$} \\
\hline атоA-1F/amoA-2R-GC clamp ${ }^{\mathrm{a}}$ & AOB $\beta$-Proteobacteria & Second PCR for DGGE & $\begin{array}{l}3 \mathrm{~min} \text { at } 95^{\circ} \mathrm{C} \text {, followed by } 10 \text { cycles } \\
\text { of } 30 \mathrm{~s} \text { at } 95{ }^{\circ} \mathrm{C}, 45 \mathrm{~s} \text { at } 60{ }^{\circ} \mathrm{C} \text { with } \\
\text { a } 0.5{ }^{\circ} \mathrm{C} \text { decrease per cycle and } 60 \mathrm{~s} \\
\text { at } 72{ }^{\circ} \mathrm{C} \text {, followed by } 30 \text { cycles of } \\
30 \mathrm{~s} \text { at } 94{ }^{\circ} \mathrm{C}, 45 \mathrm{~s} \text { at } 55^{\circ} \mathrm{C} \text { and } 60 \mathrm{~s} \\
\text { at } 72{ }^{\circ} \mathrm{C} \text {, and a final elongation step } \\
\text { of } 10 \mathrm{~min} \text { at } 72{ }^{\circ} \mathrm{C}[32]\end{array}$ & {$[30]$} \\
\hline $\begin{array}{l}\text { Arch-amoAF/Arch-amoAR-GC } \\
\text { clamp }^{\text {a }}\end{array}$ & $\mathrm{AOA}$ & Second PCR for DGGE & $\begin{array}{l}5 \text { min at } 95{ }^{\circ} \mathrm{C} \text {, followed by } 30 \text { cycles } \\
\text { of } 45 \mathrm{~s} \text { at } 95^{\circ} \mathrm{C}, 45 \mathrm{~s} \text { at } 54{ }^{\circ} \mathrm{C} \text { with } \\
\text { a } 0.2^{\circ} \mathrm{C} \text { increment per cycle, and } \\
60 \mathrm{~s} \text { at } 72{ }^{\circ} \mathrm{C} \text {, and a final elongation } \\
\text { step of } 10 \mathrm{~min} \text { at } 72{ }^{\circ} \mathrm{C}\end{array}$ & {$[11]$} \\
\hline
\end{tabular}

${ }^{\text {a }}$ GC clamp: 5' CGCCCGCCGCGCGCGGCGGGCGGGGCGGGGGCACGGGGGG 3' [33]

evenness, and diversity estimators, respectively) were calculated based on a subsampled OTU table of 950 sequences (to fit the smallest library size obtained), since these metrics tend to vary with library size. All these metrics were calculated using QIIME v 1.9.1 [35]. The Bray-Curtis beta diversity index was calculated using PRIMER-E v 7 [37] to measure similarity between soil samples. Before Bray-Curtis index calculation, relative abundances of each OTU in a soil sample were calculated by dividing OTU abundance by the total amount of sequences in that sample; then OTU relative abundances were square root-transformed to down-weight the importance of very abundant species [38]. The Bray-Curtis similarity matrix was further used to evaluate similarities in microbial community structure of soils covered by A. germinans and $R$. mangle.

\section{Statistical and Ordination Analyses}

Differences in community alpha diversity estimators (total observed OTUs, Simpson evenness $(1 / \mathrm{D} / \mathrm{S})$, and the Shannon $\left(\mathrm{H}^{\prime}\right)$ indices) in soils underneath $A$. germinans and $R$. mangle were tested with a nonparametric Kruskal Wallis test [39], as pairwise comparisons within each sampling site. Nonmetric multidimensional scaling (NMDS) and cluster analyses were performed to evaluate similarities in soil microbial community structures, based on a Bray-Curtis similarity matrix of (square root-transformed) 16S rRNA OTU relative abundances. Further, a Permutational Multivariate Analysis of
Variance (PERMANOVA) [40], based on the same BrayCurtis similarity matrix, and an analysis of similarities (ANOSIM) were performed to test for significant differences in overall microbial community structures. In soil samples with different community structures due to mangrove species (detected by cluster and ANOSIM analyses), a Similarity Percentages (SIMPER) analysis of taxonomically classified sequences (phylotype-based approach) was performed to detect the taxa with larger contributions to those differences, using PRIMER-E v 7 [37]. The similarity in AOA and AOB community composition (obtained by PCR-DGGE of amoA genes) was evaluated by a cluster analysis of the banding pattern of DGGE based on the Sorensen similarity index. Further, similarities in the composition of AOB of the family Nitrosomonadaceae (obtained by MiSeq analysis) were evaluated by cluster and ANOSIM analyses. All multivariate analyses were performed using PRIMER-E v 7 [37].

Differences in the abundance of (log-transformed) amoA genes from $\mathrm{AOB}$ and $\mathrm{AOA}$ in response to the mangrove species within each location were tested using one-way ANOVA (previous testing the assumptions of normality and homoscedasticity). The similarity in soil environmental factors of samples underneath different mangrove species and from different sampling locations was explored by principal component analysis (PCA). Before PCA, environmental variables measured as concentrations were log-transformed and all environmental variables were standardized to zero mean and standard deviation of one, to avoid different measure units in the multivariate analysis. 


\section{Accession Number}

Sequences of bacterial and archaeal 16S rRNA genes were deposited in the European Nucleotide Archive (ENA) under the accession number PRJEB22120.

\section{Results}

\section{Abundance of AOA and AOB}

The effect of mangrove species on the abundance of AOA and $\mathrm{AOB}$ was studied by quantifying the archaeal and bacterial amoA genes in samples of soils covered with A. germinans and $R$. mangle. The abundance of amoA genes from AOA ranged from $4.4 \pm 8.0 \times 10^{4}$ to $1.7 \pm 1.3 \times 10^{7}$ gene copies per microgram DNA (Fig. 1). In contrast, bacterial amoA genes ranged from abundances below the quantification limit of the assay (1200 gene copies per $\mu \mathrm{g}$ DNA) to $1.5 \pm 1.2 \times 10^{5}$ gene copies per $\mu \mathrm{g}$ DNA and were outnumbered by archaeal genes by ratios of 6 to $1.6 \times 10^{5}$ (Fig. 1). We observed significant effects of mangrove species on AOA gene abundance only in soil samples from PI, where soils covered with $R$. mangle had almost three orders of magnitude higher gene abundances than soils covered with A. germinans $(p<0.005)$. In soil samples from the two remaining locations, AOB genes were significantly more abundant in soils covered with $R$. mangle than in those underneath $A$. germinans $\left(p_{\mathrm{NHI}}=0.01, p_{\mathrm{SHI}}=0.03\right)$.

\section{Composition of AOB and AOA Communities}

Our first approach to test the effect of tree species on the community composition of ammonia oxidizers was performed by PCR-DGGE based on amoA genes. With respect to the archaeal amoA gene, samples of soils covered with A. germinans separated completely from samples of soil covered by $R$. mangle, except for only two samples from NHI (i.e., NHI-A1 and NHI-A4, Fig. S1). In contrast, cluster analyses of bacterial amoA genes showed different results at each location. Samples of soils from SHI covered with $R$. mangle grouped together with similarity values higher than $70 \%$, but those covered with A. germinans did not group altogether. Except for one of the Avicennia locations that showed low amplification product (i.e., NHI-A4), soil samples from NHI showed very similar banding patterns (higher than $80 \%$ similar), independently of the type of mangrove covering the soil. Lastly, cluster analysis of soil samples from PI could not be performed, due to very weak bands or lack of amplification of the amoA genes from AOB in most of the samples (probably due to low gene abundance in samples from this site).

We further analyzed the effect of tree species on ammonia oxidizer community composition by MiSeq analysis of $16 \mathrm{~S}$ rRNA genes in soil samples. Within the bacteria, sequences assigned to the genus Nitrosomonas were detected in all samples, at abundances between 0.3 and $0.9 \%$ of the total number of sequences. The genera Nitrosospira and Nitrosococcus were not detected, although it is possible that sequences within the families Nitrosomonadaceae and Chromatiaceae that were classified as uncultured or could not be classified at the genus level, were related to these genera, respectively. Cluster and

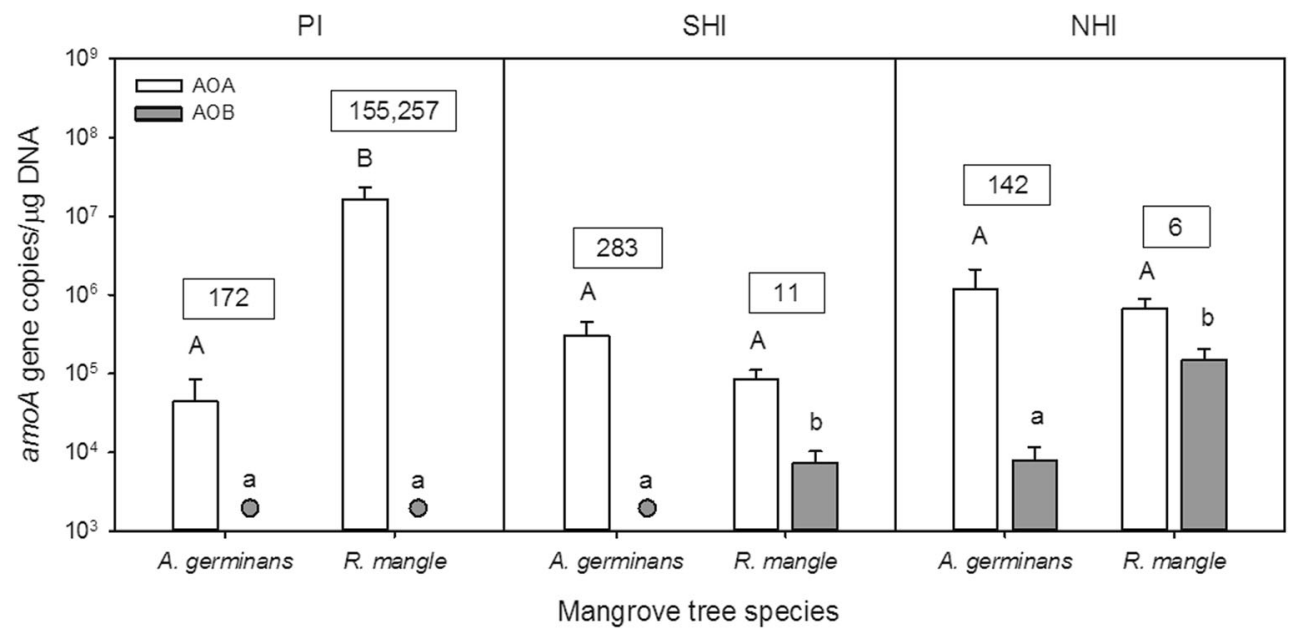

Fig. 1 Abundance of archaeal (AOA) and bacterial (AOB) amoA gene copies in samples of soil covered with Avicennia germinans and Rhizophora mangle. Error bars represent the standard error of the data $(n=4)$. Abundances of bacterial gene copies below the quantification limit of the assay (1200 gene copies per $\mu \mathrm{g}$ DNA) are represented by gray circles. The ratio of archaeal to bacterial amoA genes (AOA/AOB) is indicated in the boxes on top of the bars. Within each location, significant differences in the abundance of amoA genes in soils covered with different mangrove species are indicated with different letters above the bars (uppercase letters, comparisons between archaeal amoA genes; lowercase letters, comparisons between bacterial amoA genes) 
ANOSIM analyses based on sequences classified as Nitrosomonadaceae completely separated soil samples covered by $A$. germinans from those covered by $R$. mangle within locations SHI and PI, but not within NHI (cluster analysis in Fig. $\mathrm{S} 2$, and ANOSIM global $R=0.568(p=0.001), R_{\mathrm{SHI}}=0.792$, $R_{\mathrm{PI}}=1, R_{\mathrm{NHI}}=0$ ). In contrast to $\mathrm{AOB}$, known AOA genera were not detected in soil samples. This is probably a consequence of the low abundance of cultured Archaea in the 16S rRNA databases, since 34 to $88 \%$ of the archaeal sequences were assigned to uncultured microorganisms at the genus level.

\section{Bacterial and Archaeal Community Structure and Diversity}

A total of 117,649 reads were obtained from 19 soil samples, with an average of 7740 sequences per sample. Five samples (NHI-A2, NHI-R3, PI-A1, PI-R1, and PI-R2) were discarded from further analyses because they produced less than 500 reads. The Good's coverage index was on average higher than $90 \%$, suggesting that sequencing effort was good in most samples (Table 2). In soil samples from PI, OTU richness, the Simpson evenness, and Shannon diversity indices were significantly higher in soils underneath $R$. mangle than in soils beneath A. germinans ( $p<0.01$, Table 2$)$. Soil samples from the other locations did not show significant differences in richness, diversity, and evenness between both mangrove species.

The grouping of sequences at a $97 \%$ similarity threshold resulted in 3925 OTUs, of which 153 were classified as Archaea, 3593 as Bacteria, and 179 were unclassified. Bacteria represented 83.4 to $98.7 \%$ of the $16 \mathrm{~S}$ rRNA sequences from soil samples, and were on average 50-fold more abundant than Archaea, that represented 0.7 to $15.9 \%$ of the total soil sequences. The most representative bacterial phyla were Proteobacteria (relative abundance 45.1-82.6\%), Actinobacteria (3.0-11.5\%), Bacteroidetes (1.2-19.6\%), Chloroflexi (1.3-25.1\%), Planctomycetes (0.8-8.0\%), Acidobacteria (1.4-6.1\%), Gemmatimonadetes $(0.8-5.2 \%)$, and Firmicutes $(0.4-10.0 \%)$ (Fig. 2a). In addition, 36 bacterial phyla were detected at lower abundances $(<1 \%$ average among all samples). Regarding the archaeal community, the dominant phylum was Bathyarchaeota (19.5-80.2\%), followed by Thaumarchaeota (2.4-73.0\%), Euryarchaeota (1.4-41.9\%), Woesearchaeota (0-17.0\%), and Lokiarchaeota $(0-14.6 \%)$. The remaining sequences were either at low abundance $(<1 \%$ average among all samples), or classified as uncultured Archaea (Fig. 2b).

A PERMANOVA test revealed that the community structures in soil samples from different locations and mangrove cover differed significantly (Pseudo- $F=3.15, p=0.001$ ). Further, an analysis of OTUs at $97 \%$ similarity showed that soil samples from PI and SHI underneath a single mangrove cover had similar microbial community structures, as revealed by cluster and NMDS analyses (Fig. 3). In contrast, soil samples from NHI did not group together, although two soil samples from this location underneath $A$. germinans (NHI-A1 and NHI-A4) grouped with soil samples from another location but with similar vegetation cover (PI-A group, Fig. 3). An analysis of similarities (ANOSIM) confirmed the differences in community structures of soil samples from different locations and mangrove species (global $R=0.754, p<0.001$ ), and pairwise comparisons detected differences in community structures due to mangrove species cover in soil samples from SHI $(R=1)$ and PI $(R=1)$, but not in samples from NHI $(R=0.37)$. Further, a SIMPER analysis was performed to detect the taxa that mostly contributed to differences between mangrove species in SHI and PI. This analysis showed that bacterial genera with larger contributions to differences in community structure due to mangrove species were Marinifilum and Tenacibaculum belonging to the phylum Bacteroidetes, and Pseudolabrys, Arcobacter, Sulfurimonas, Sulfurovum, Thioalkalispira, and Sedimenticola of the phylum Proteobacteria in SHI; and uncultured Anaerolineaceae of the phylum Chloroflexi and Sulfurovum and Thioalkalispira of the phylum Proteobacteria in PI (Table S1). Archaeal groups with larger contributions to differences between mangrove species were uncultured Bathyarchaeota, Methanococcoides, uncultured and unclassified archaea belonging to the Marine Benthic Group D (DHVEG-1) of the phylum Euryarchaeota, and uncultured archaea of the Marine group I of the phylum Thaumarchaeota in SHI; and uncultured Bathyarchaeota, uncultured Lokiarchaeota, and uncultured and unclassified archaea of the phylum Thaumarchaeota in PI (Table S2).
Table 2 Soil microbial alpha diversity estimators based on OTUs at $97 \%$ similarity (average \pm standard error). Significant differences in pairwise comparison within the same sampling site are indicated with asterisks $(* * p<0.01)$

\begin{tabular}{|c|c|c|c|c|}
\hline Sample & Good's coverage $^{\mathrm{a}}$ & Observed OTUs $^{\mathrm{b}}$ & Simpson evenness $(1 / \mathrm{D} / \mathrm{S})^{\mathrm{b}}$ & Shannon $\left(\mathrm{H}^{\prime}\right)^{\mathrm{b}}$ \\
\hline PI-A & $0.94 \pm 0.03$ & $312 \pm 30.5^{\text {** }}$ & $0.035 \pm 0.013^{* *}$ & $5.98 \pm 0.58^{* *}$ \\
\hline PI-R & $0.94 \pm 0.03$ & $449 \pm 25.2^{* * *}$ & $0.248 \pm 0.046^{* *}$ & $8.00 \pm 0.20^{* *}$ \\
\hline SHI-A & $0.95 \pm 0.01$ & $368 \pm 26.0$ & $0.141 \pm 0.073$ & $7.14 \pm 0.36$ \\
\hline SHI-R & $0.89 \pm 0.02$ & $388 \pm 25.3$ & $0.171 \pm 0.077$ & $7.32 \pm 0.45$ \\
\hline NHI-A & $0.92 \pm 0.04$ & $384 \pm 7.7$ & $0.219 \pm 0.048$ & $7.64 \pm 0.14$ \\
\hline NHI-R & $0.84 \pm 0.06$ & $379 \pm 47.2$ & $0.162 \pm 0.079$ & $7.08 \pm 0.81$ \\
\hline
\end{tabular}

${ }^{\text {a }}$ Calculation based on all the sequences of each sample

${ }^{\mathrm{b}}$ Calculation based on a subsampled OTU table of 950 sequences, to fit the size of the smallest library 
Fig. 2 Relative abundance of bacterial (a) and archaeal (b) phyla in forest soils dominated by Avicennia germinans (PI-A, SHIA and NHI-A) or Rhizophora mangle (PI-R, SHI-R and NHI-R)

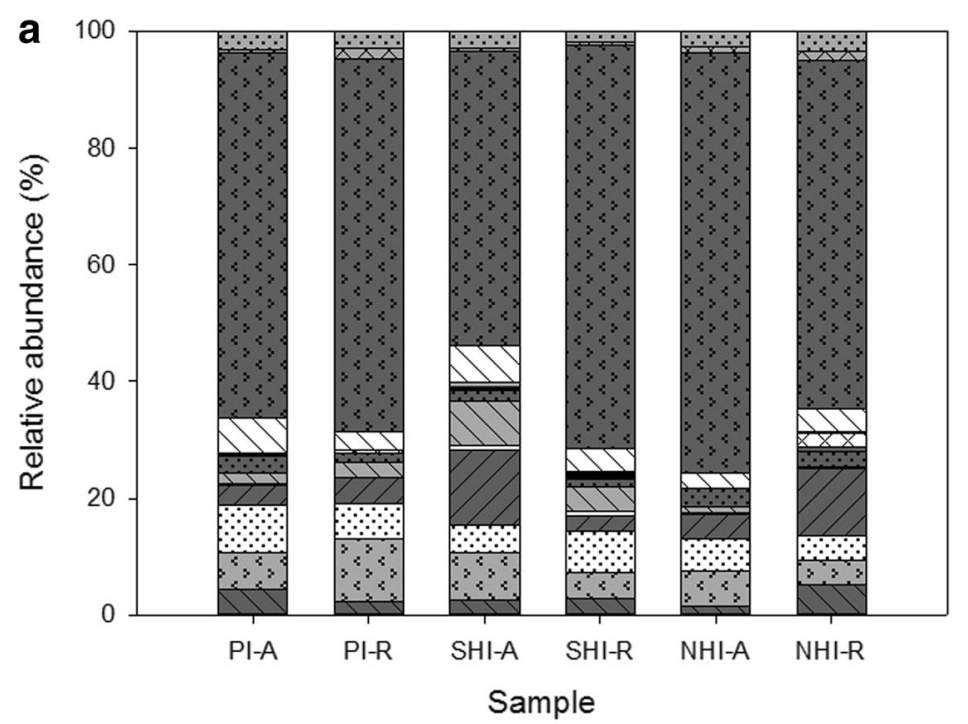

17 Acidobacteria $\because$ Actinobacteria $\because$ Bacteroidetes 7 Chloroflexi $\square$ Cyanobacteria $\square$ Fimicutes $\because$ Gemmatimonadetes $\square$ Ignavibacteriae - Marinimicrobia $\nabla \times$ Nitrospirae $\square$ Parcubacteria $\square$ Planctomycetes $\because$ Proteobacteria $\times \times$ Spirochaetae $\because \cdots$ Others $(<1 \%)$ $\because$ Unclassified

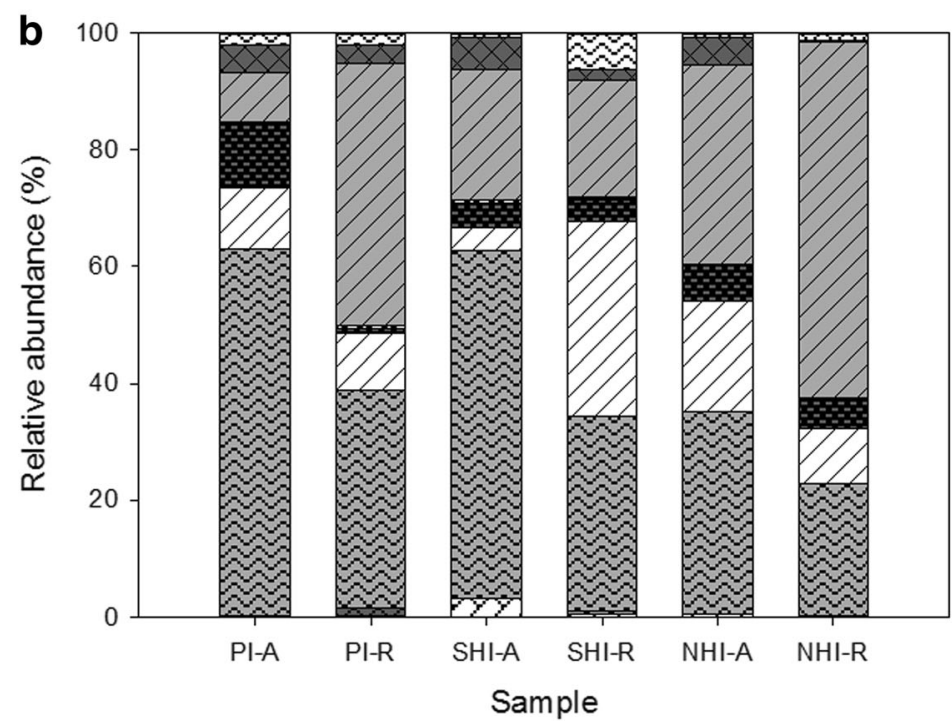

$\square \sqsupset$ Aenigmarchaeota 모요명 AK8 ad Altiarchaeales $\$$ Bathyarchaeota 77 Euryarchaeota Lokiarchaeota MEG Group $\infty$ MHVG Group $\checkmark \backslash$ Thaumarchaeota W Woesearchaeota $\square$ uncultured archaea $\square$ Others $(<1 \%)$

\section{Soil Physicochemical Properties}

Physicochemical properties of soil samples are reported in Table S3. By pairwise comparison per sampling location,
A. germinans soil samples had higher concentrations of some nutrients (i.e., sulfur, calcium, and magnesium), although $R$. mangle soil samples had higher concentrations of iron. In addition, samples of soils covered with A. germinans were
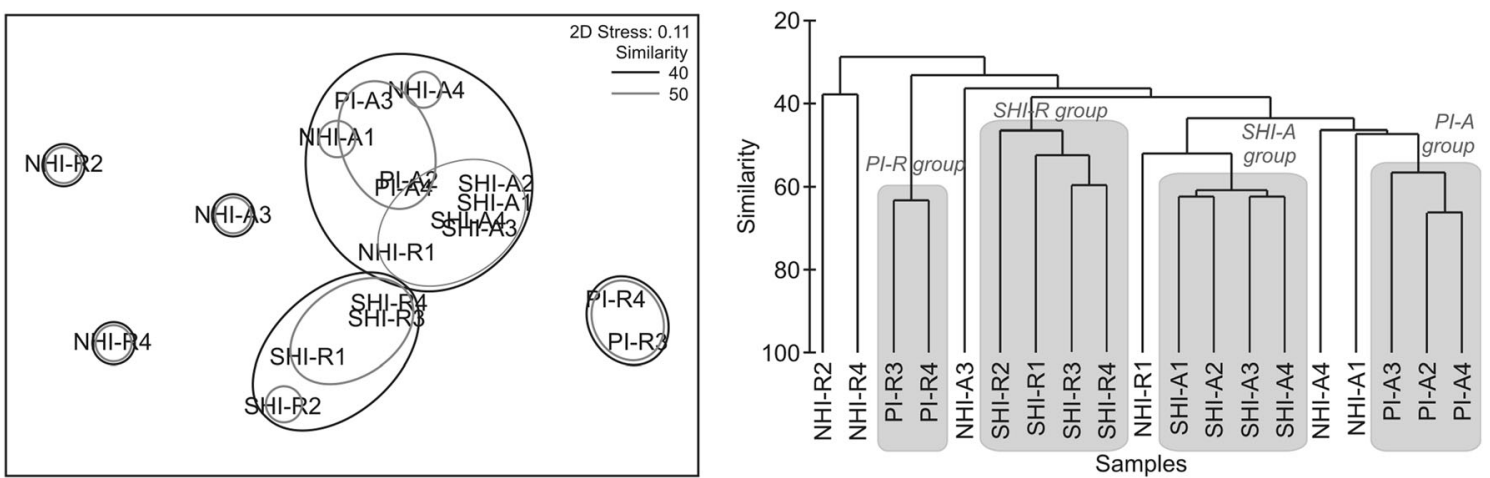

Fig. 3 NMDS (left panel) and cluster (right panel) analyses based on Bray-Curtis similarities of microbial communities from soil samples dominated by Avicennia germinans (PI-A, SHI-A and NHI-A) or Rhizophora mangle (PI-R, SHI-R and NHI-R) 
slightly more saline (with higher concentrations of sodium) than those covered with $R$. mangle trees. Salinity was usually above seawater levels, $\mathrm{pH}$ values were generally neutral (except for SHI-A that was slightly more acidic) and TOC was lower in soil samples from NHI than in those from PI and SHI, as previously reported [28].

We used PCA to explore the differences in physicochemical properties between soil samples (Fig. S3). The first principal component (PC1) explained $58.4 \%$ of the variation and was determined by several variables with relatively equal importance (nickel, chromium, zinc, magnesium, cobalt, sodium, TOC, particle size, potassium, copper, salinity, iron, sulfate, phosphorus, aluminum, and sulfur). This PC completely separated samples from tidal locations (PI-A, PI-R, SHI-A, and SHI-R, to the left of the graph) from samples retrieved at non-tidal locations (NHI-A and NHI-R, to the right). The second principal component (PC2) explained 19.9\% of the variation, which led to a total explanation of the variation of $78.3 \%$. Manganese, calcium, and iron were the variables that mostly contributed to the determination of PC2.

\section{Discussion}

In this study, we aimed to elucidate the effect of two species of globally distributed mangrove genera (Avicennia and Rhizophora) on ammonia-oxidizing microbial communities in the soil. Avicennia and Rhizophora differ in their resource acquisition and survival strategies, stress tolerance, root adaptations, and tissue chemistry, and are therefore adapted to different zones in a tidal gradient. We hypothesized that species of ammonia-oxidizing archaea and bacteria, like mangrove species, are adapted to specific tidal zones and hence indirectly coupled with specific mangrove species. This hypothesis was confirmed for the community composition of the ammonia oxidizers at the two tidal locations (PI and SHI), but did not apply to the non-tidal location of NHI, reflecting the results previously obtained with samples from the same mangrove locations when the sulfate-reducing community was studied [41]. Moreover, the difference observed for community structures of $\mathrm{AOA}$ and $\mathrm{AOB}$ was reflected by the difference in 16S rRNA gene community structures for the whole archaeal and bacterial communities, i.e., only differences at the tidal locations. The presence of differences in microbial communities only at the tidal locations and not at the non-tidal location demonstrates that the microbial community structure is primarily governed by the presence of a tidal regime, and not by the dominant mangrove species. The fact that no differences were observed between the soil samples collected from beneath $A$. germinans and $R$. mangle at the non-tidal location implies that a differential effect on the soil microbial community triggered by these species is rather limited.
Two different tools were used to test for differences in ammonia-oxidizing communities in soils underneath A. germinans or $R$. mangle. On the one hand, the DGGE analysis based on amoA genes detected differences in AOA communities associated with different mangrove species, but was not able to detect differences in $\mathrm{AOB}$, probably because this fingerprinting technique does not have enough resolution power to detect differences in $a m o A$ genes of $\mathrm{AOB}$ present at low abundance. On the other hand, cluster and ANOSIM analyses of Nitrosomonadaceae sequences obtained by MiSeq completely separated soil samples covered by A. germinans from those covered by $R$. mangle at both tidal locations, although this technique was not able to detect differences in AOA composition. This may be a consequence of the low abundance of cultured representatives of archaea in 16S rRNA databases used to classify sequences, since 34 to $88 \%$ of the archaeal sequences in this study were assigned to uncultured microorganisms at the genus level. In accordance, it has been reported that 14 of the 20 existing archaeal phyla have no cultured representatives, and that among the phyla with cultured representatives, only $1.7 \%$ of the sequences came from cultures (the remaining sequences coming from culture-independent approaches) [42]. Overall, these two approaches revealed complementary information about the composition of $\mathrm{AOB}$ and $\mathrm{AOA}$ in these mangrove soils.

In comparison to soil beneath $A$. germinans, soils associated with $R$. mangle had a higher abundance of AOA genes at PI, and of AOB genes at NHI and SHI. Hence, the effect of mangrove species on the sizes of the AOA and AOB communities were different for the east and west coast of Florida, whereas tide had apparently, no effect on the relative sizes of both ammonia-oxidizing communities at the east coast. Since the effects on the relative community sizes of $\mathrm{AOA}$ and $\mathrm{AOB}$ are site-specific and not mangrove species-specific, the responsible mechanism behind the observed differences must also be site-specific. Because total nutrient concentrations were the lowest in $R$. mangle soil samples from PI, the high relative abundance of AOA in these soils could be related to the capacity of these ammonia oxidizers to thrive and outcompete AOB in oligotrophic environments [43, 44]. Further studies should be directed to identify site-specific soil and environmental characteristics that could be influencing the abundances of AOA and AOB communities.

Studies of the relationship between AOB and AOA abundances in mangrove ecosystems have hitherto shown contrasting results. Mangroves from the Mai Po Marshes Nature Reserve (China) dominated by $K$. obovata showed higher abundances of bacterial than archaeal amoA genes (AOB/ AOA gene ratio ca. 1 to 12 ) and suggested that $\mathrm{AOB}$ might play a more important role in mangrove sediments than AOA [20]. A seasonal study under vegetated and non-vegetated sediments in the same Nature Reserve showed slightly higher abundances of $\mathrm{AOB}$ than $\mathrm{AOA}$ genes, with $\mathrm{AOB} / \mathrm{AOA}$ gene 
ratio ranging from 0.7 to 3.6 [17]. Further studies performed in Chinese mangrove ecosystems showed that not only bacterial $a m o A$ genes but also gene transcripts were more abundant than those of archaea [16, 18]. In contrast, other studies found higher abundances of archaeal than bacterial ammonia oxidizers in mangrove sediments. In polluted mangrove sediments from China, archaeal amoA genes were 1.8 to 6.3 times more abundant than their bacterial counterpart, and the AOA/ AOB ratio was correlated with ammonium concentration [19]. Besides these studies in Southeast Asia, a previous study in sediments covered with $A$. germinans at the coast of Florida showed a dominance of archaeal over bacterial amo $A$ genes independently of sampling year, impoundment sampled or mangrove vegetation cover type, with $\mathrm{AOA} / \mathrm{AOB}$ gene ratios varying largely between 0.9 and $6.5 \times 10^{4}$ [15]. Our results agreed with these latter results in that AOA genes were up to several orders of magnitude more abundant than those of $\mathrm{AOB}$ and further support a dominance of AOA over AOB in mangrove sediments from this region. These results may suggest that AOB could be more sensitive and more easily influenced by environmental factors as previously observed by Cao and colleagues [19], whereas AOA are probably less sensitive and therefore became dominant in this environment. Alternatively AOA may be more resistant to decay than AOB. Measuring amoA transcripts might be a way to resolve this problem, but then it should be kept in mind that inactive AOA may preserve their amoA transcripts for a longer period than inactive AOB [45].

In general, the effect of mangrove species on total soil bacterial and archaeal community compositions has hardly been characterized. Bacterial communities in the rhizospheres of Avicennia schaueriana and Laguncularia racemosa and archaeal communities in the rhizospheres of $R$. mangle and L. racemosa from Brazil showed some differences in their composition, although the main variation was between the rhizosphere of either mangrove tree and the bulk sediment communities [24, 25]. Archaeal communities were also studied in mangroves from China, and differences were found between communities associated to $K$. candel or Bruguiera gymnoihiza and those associated to L. racemosa or Sonneratia apetala mangroves [22].

At PI, differences in the bacterial component of the microbial community were mostly attributed to increased abundances of Sulfurovum and Thioalkalispira in soils covered by $A$. germinans and $R$. mangle, respectively. These bacteria are both halophilic, facultative anaerobes or microaerophiles, and sulfur or thiosulfate oxidizers $[46,47]$ that may play similar roles in the cycling of sulfur in both soil types, but are specifically enriched by unknown habitat-specific characteristics. Soils underneath $A$. germinans also had higher abundances of uncultured Lokiarchaeota and Bathyarchaeota, and lower abundance of Thaumarchaeota than the soils covered by R. mangle. Bathyarchaeota and Thaumarchaeota, which together represented 43.3 to $94.3 \%$ of the archaeal sequences in these mangroves, have been detected in diverse habitats and often at high abundances, suggesting a high ability to adapt to different environmental conditions, probably as a result of versatile metabolic pathways [48, 49]. Regarding the phylum Lokiarchaeota, it seems to be abundant and widely distributed in deep sediments, but also in mangrove soils [50]. Although so far little is known about this group since archaea of this phylum have never been isolated or enriched [51], they could play a role in anaerobic biogeochemical processes such as sulfate reduction or methane oxidation [52]. In agreement with this, mangrove soils tend to be dominated by anaerobic methanogens and sulfate-reducing bacteria [24, 25, 53].

Several microorganisms contributed to the differences in community structures of soils covered by A. germinans and $R$. mangle in SHI. $R$. mangle-covered soils had a higher abundance of strictly or facultative anaerobic bacteria of the genera Sedimenticola, Thioalkalispira, and Marinifilum, and a lower abundance of Pseudolabrys than A. germinans-covered soils. Hardly anything is known about the ecology of Pseudolabrys [54]; however, its higher abundance in soils underneath $A$. germinans than $R$. mangle could be related to its aerobic metabolism and the capacity of Avicennia species to maintain more oxidized soil conditions than Rhizophora [55]. However, also anaerobic and microaerophilic bacteria (Sulfurovum, Arcobacter, Tenacibaculum) dominated A. germinans-covered soils in SHI, showing the dynamic character of tidal mangrove soils with respect to oxygen availability. Except for Sulfurovum, these genera were present at high abundance in only one of the samples and nearly absent in all the others; therefore, we cannot generalize that their abundance is related to a particular mangrove species. Uncultured and unclassified archaea belonging to the Marine Benthic Group D were more abundant underneath $R$. mangle than A. germinans soils. This lineage belongs to the class Thermoplasmata, a group of facultatively anaerobic, thermoacidophilic archaea capable of respiring sulfur [56]. In spite of their acidophilic metabolism, Thermoplasmata have been previously detected at very high abundances ( $70.4 \%$ of the archaeal sequences) in mangrove soils of neutral $\mathrm{pH}$ [57]. In accordance, we found a high abundance of these archaea in soil samples of neutral $\mathrm{pH}$ and with high concentrations of sulfur. Therefore, it could be possible that they were growing in acidic microenvironments within these mangrove soils where elemental sulfur is reduced to $\mathrm{H}_{2} \mathrm{~S}$.

In contrast to SHI and PI, the non-tidal location NHI showed no differences in microbial communities from A. germinans- and $R$. mangle-covered soils. This result reflects the results obtained with samples from the same mangrove locations when sulfate reduction characteristics were studied [41]. At the tidal locations PI and SHI, steady state sulfate reduction rates, and $d s r B$ gene copy numbers were higher at the $A$. germinans than at the $R$. mangle stands, 
although not significantly for the numbers at PI. At the nontidal NHI location, results were mixed with respect to the sulfate reduction traits. Impounding can cause limited tidal exchange, changes in water quality [58], in salinity due to hydrological alterations and evapotranspiration [59], in sediment chemistry, nutrient dynamics and redox conditions [29, 60], in plant and fish communities [61], and also in soil microbial communities [41]. In this study, the limited tidal exchange at the impounded location of NHI might have had a stronger effect on microbial communities than vegetation, since the microbial communities had very variable compositions independently of the plant cover, which precluded us from finding a characteristic microbiome associated with each mangrove species at this location. In accordance, the PCA based on soil physicochemical properties from our study completely separated soil samples retrieved at tidal stations from those collected at the non-tidal location, independently of the vegetation cover, suggesting that tide instead of mangrove species had the largest effect on soil physicochemical properties. Nonetheless, this represents a first exploratory description of mangrove soil physicochemical properties, and further studies should be performed to establish their effect on the soil microbial communities in tidal and non-tidal locations.

Overall, this is the first study that compares the effect of two different species of globally distributed mangrove genera (Rhizophora and Avicennia) on soil bacterial and archaeal communities, and on the functional group of ammonia oxidizers. Mangrove trees influenced both the composition of $\mathrm{AOA}$ and $\mathrm{AOB}$ and that of the overall soil microbial communities, but only in locations exposed to tides. The absence of tidal exchange in the impounded location might have had a stronger effect on community compositions than the vegetation cover. In addition, we showed that the relative abundances of archaeal and bacterial amoA genes is site-specific and not mangrove tree-specific. However, independently of site and mangrove species, AOA outnumbered AOB at all sampling locations, suggesting a dominance of archaeal over bacterial ammonia oxidizers in mangrove sediments from this region.

Acknowledgements The Consejo Nacional de Investigaciones Científicas y Técnicas (CONICET) supported the postdoctoral fellow and the traveling grant of Magalí S. Marcos to the Netherlands. We wish to thank Drs. Melike Balk, Mariet Hefting, Joost Keuskamp, Jos Verhoeven, and Dennis Whigham for their assistance in collecting the soil samples. This is publication number 6387 of the Netherlands Institute of Ecology and publication number 1075 of the Smithsonian Marine Station.

\section{Compliance with Ethical Standards}

Conflict of Interest The authors declare that they have no conflict of interest.
Open Access This article is distributed under the terms of the Creative Commons Attribution 4.0 International License (http:// creativecommons.org/licenses/by/4.0/), which permits unrestricted use, distribution, and reproduction in any medium, provided you give appropriate credit to the original author(s) and the source, provide a link to the Creative Commons license, and indicate if changes were made.

\section{References}

1. Walters BB, Rönnbäck P, Kovacs JM, et al. (2008) Ethnobiology, socio-economics and management of mangrove forests: a review. Aquat Bot 89:220-236. https://doi.org/10. 1016/j.aquabot.2008.02.009

2. Smith III TJ (1992) Forest structure. In: Robertson AI, Alongi DM (eds) Trop. mangrove Ecosyst. Washington D.C., pp 101-136

3. Mckee KL (1993) Soil physicochemical patterns and mangrove species distribution - reciprocal effects? J Ecol 81:477-487. https://doi.org/10.2307/2261526

4. FAO (2007) The world's mangroves 1980-2005. Rome

5. McKee KL (1995) Interspecific variation in growth, biomass partitioning, and defensive characteristics of neotropical mangrove seedlings: response to light and nutrient availability. Am J Bot 82: 299-307

6. Alongi DM, Tirendi F, Clough BF (2000) Below-ground decomposition of organic matter in forests of the mangroves Rhizophora stylosa and Avicennia marina along the arid coast of Western Australia. Aquat Bot 68:97-122. https://doi.org/10.1016/S03043770(00)00110-8

7. Rao RG, Woitchik AF, Goeyens L, et al. (1994) Carbon, nitrogen contents and stable carbon isotope abundance in mangrove leaves from an east African coastal lagoon (Kenya). Aquat Bot 47:175183. https://doi.org/10.1016/0304-3770(94)90012-4

8. Keuskamp JA (2014) Decomposition and soil carbon sequestration in mangrove ecosystems. PhD Thesis. Utrecht University

9. Schleper C, Nicol GW (2010) Ammonia-Oxidising Archaea - physiology, ecology and evolution. Adv Microb Physiol 57:1-41. https://doi.org/10.1016/B978-0-12-381045-8.00001-1

10. Kowalchuk GA, Stephen JR (2001) Ammonia-oxidizing bacteria: A model for molecular microbial ecology. Annu Rev Microbiol 55: 485-529. https://doi.org/10.1146/annurev.micro.55.1.485

11. Francis CA, Roberts KJ, Beman JM, et al. (2005) Ubiquity and diversity of ammonia-oxidizing archaea in water columns and sediments of the ocean. Proc Natl Acad Sci USA 102:14683-14688. https://doi.org/10.1073/pnas.0506625102

12. Junier P, Molina V, Dorador C, et al. (2010) Phylogenetic and functional marker genes to study ammonia-oxidizing microorganisms $(\mathrm{AOM})$ in the environment. Appl Microbiol Biotechnol 85:425440. https://doi.org/10.1007/s00253-009-2228-9

13. Prosser JI, Nicol GW (2012) Archaeal and bacterial ammoniaoxidisers in soil: the quest for niche specialisation and differentiation. Trends Microbiol 20:523-531. https://doi.org/10.1016/j.tim. 2012.08.001

14. Laanbroek HJ, Keijzer RM, Verhoeven JTA, Whigham DF (2012) The distribution of ammonia-oxidizing betaproteobacteria in stands of Black mangroves (Avicennia germinans). Front Microbiol 3:111. https://doi.org/10.3389/fmicb.2012.00153

15. Laanbroek HJ, Keijzer RM, Verhoeven JTA, Whigham DF (2013) Changes in community composition of ammonia-oxidizing betaproteobacteria from stands of Black mangrove (Avicennia germinans) in response to ammonia enrichment and more oxic conditions. Front Microbiol 4:1-9. https://doi.org/10.3389/fmicb. 2013.00343 
16. Li M, Gu JD (2013) Community structure and transcript responses of anammox bacteria, $\mathrm{AOA}$, and $\mathrm{AOB}$ in mangrove sediment microcosms amended with ammonium and nitrite. Appl Microbiol Biotechnol 97:9859-9874. https://doi.org/10.1007/s00253-0124683-y

17. Wang YF, Feng YY, Ma X, Gu JD (2013) Seasonal dynamics of ammonia/ammonium-oxidizing prokaryotes in oxic and anoxic wetland sediments of subtropical coastal mangrove. Appl Microbiol Biotechnol 97:7919-7934. https://doi.org/10.1007/ s00253-012-4510-5

18. Wang H, Su J, Zheng T, Yang X (2015) Insights into the role of plant on ammonia-oxidizing bacteria and archaea in the mangrove ecosystem. J Soils Sediments 15:1212-1223. https://doi.org/10. 1007/s11368-015-1074-x

19. Cao H, Li M, Hong Y, Gu JD (2011) Diversity and abundance of ammonia-oxidizing archaea and bacteria in polluted mangrove sediment. Syst Appl Microbiol 34:513-523. https://doi.org/10.1016/j. syapm.2010.11.023

20. Li M, Cao H, Hong Y, Gu JD (2011) Spatial distribution and abundances of ammonia-oxidizing archaea (AOA) and ammoniaoxidizing bacteria (AOB) in mangrove sediments. Appl Microbiol Biotechnol 89:1243-1254. https://doi.org/10.1007/s00253-0102929-0

21. Wickramasinghe S, Borin M, Kotagama SW, et al. (2009) Multifunctional pollution mitigation in a rehabilitated mangrove conservation area. Ecol Eng 35:898-907. https://doi.org/10.1016/j. ecoleng.2008.12.021

22. Li W, Guan W, Chen H, et al. (2016) Archaeal communities in the sediments of different mangrove stands at Dongzhaigang, China. J Soils Sediments 16:1995-2004. https://doi.org/10.1007/s11368016-1427-0

23. Yang Q, Lei AP, Li FL, et al. (2014) Structure and function of soil microbial community in artificially planted Sonneratia apetala and S. caseolaris forests at different stand ages in Shenzhen Bay, China. Mar Pollut Bull 85:754-763. https://doi.org/10.1016/j.marpolbul. 2014.02.024

24. Gomes NCM, Cleary DFR, Pires ACC, et al. (2014) Assessing variation in bacterial composition between the rhizospheres of two mangrove tree species. Estuar Coast Shelf Sci 139:40-45. https://doi.org/10.1016/j.ecss.2013.12.022

25. Pires ACC, Cleary DFR, Almeida A, et al. (2012) Denaturing gradient gel electrophoresis and barcoded pyrosequencing reveal unprecedented archaeal diversity in mangrove sediment and rhizosphere samples. Appl Environ Microbiol 78:5520-5528. https:// doi.org/10.1128/AEM.00386-12

26. Prescott CE, Grayston SJ (2013) Tree species influence on microbial communities in litter and soil: current knowledge and research needs. For Ecol Manag 309:19-27. https://doi.org/10.1016/j. foreco.2013.02.034

27. Swain ED, Decker JD (2009) Development, testing, and application of a coupled hydrodynamic surface-water/groundwater model (FTLOADDS) with heat and salinity transport in the Ten Thousand Islands/Picayune Strand Restoration Project area, Florida. Reston, Virginia, USA

28. Balk M, Laverman AM, Keuskamp JA, Laanbroek HJ (2015) Nitrate ammonification in mangrove soils: a hidden source of nitrite? Front Microbiol 6:1-10. https://doi.org/10.3389/fmicb.2015. 00166

29. Verhoeven JTA, Laanbroek HJ, Rains MC, Whigham DF (2014) Effects of increased summer flooding on nitrogen dynamics in impounded mangroves. J Environ Manag 139:217-226. https:// doi.org/10.1016/j.jenvman.2014.02.035

30. Rotthauwe JH, Witzel KP, Liesack W (1997) The ammonia monooxygenase structural gene $a m o A$ as a functional marker: molecular fine-scale analysis of natural ammonia-oxidizing populations. Appl Env Microbiol 63:4704-4712
31. Laanbroek HJ, Veenhuizen PTM, Keijzer RM, Hefting MM (2017) Numerical relationships between archaeal and bacterial amoA genes vary by Icelandic Andosol classes. Microb Ecol. https://doi.org/10. 1007/s00248-017-1032-9

32. Chen X, Zhang LM, Shen JP, et al. (2010) Soil type determines the abundance and community structure of ammonia-oxidizing bacteria and archaea in flooded paddy soils. J Soils Sediments 10:1510 1516. https://doi.org/10.1007/s11368-010-0256-9

33. Muyzer G, De Waal EC, Uitterlinden AG (1993) Profiling of complex microbial populations by denaturing gradient gel electrophoresis analysis of polymerase chain reaction-amplified genes coding for 16S rRNA. Appl Environ Microbiol 59:695-700

34. Caporaso JG, Lauber CL, Walters WA, et al. (2011) Global patterns of $16 \mathrm{~S}$ rRNA diversity at a depth of millions of sequences per sample. Proc Natl Acad Sci USA 108:4516-4522. https://doi.org/ 10.1073/pnas. 1000080107

35. Caporaso JG, Kuczynski J, Stombaugh J, et al. (2010) QIIME allows analysis of high-throughput community sequencing data. Nat Methods 7:335-336. https://doi.org/10.1038/nmeth.f.303

36. Quast C, Pruesse E, Yilmaz P, et al. (2013) The SILVA ribosomal RNA gene database project: improved data processing and webbased tools. Nucleic Acids Res 41:D590-D596. https://doi.org/10. 1093/nar/gks1219

37. Clarke K, Gorley R (2015) PRIMER v7: user manual/tutorial. Plymouth Marine Laboratory, Plymouth

38. Clarke KR, Warwick RM (2001) Change in marine communities: an approach to statistical analysis and interpretation, 2nd edn. Primer-E Ltd. Plymouth Marine Laboratory, Plymouth,

39. Kruskal WH, Wallis WA (1952) Use of ranks in one-criterion variance analysis. J Am Stat Assoc 47:583-621. https://doi.org/10. 1080/01621459.1952.10483441

40. Anderson MJ (2001) A new method for non-parametric multivariate analysis of variance. Austral Ecol 26:32-46. https://doi.org/10. 1111/j.1442-9993.2001.tb00081.x

41. Balk M, Keuskamp JA, Laanbroek HJ (2016) Potential for sulfate reduction in mangrove forest soils: comparison between two dominant species of the Americas. Front Microbiol 7:1-8. https://doi. org $/ 10.3389 /$ fmicb.2016.01855

42. Schloss PD, Girard RA, Martin T, et al. (2016) Status of the archaeal and bacterial census: an update. MBio 7:e00201-16. https://doi. org/10.1128/mBio.00201-16

43. Kim H, Ogram A, Bae HS (2017) Nitrification, Anammox and denitrification along a nutrient gradient in the Florida Everglades. Wetlands 37:391-399. https://doi.org/10.1007/s13157-016-0857-1

44. Martens-Habbena W, Berube PM, Urakawa H, et al. (2009) Ammonia oxidation kinetics determine niche separation of nitrifying archaea and bacteria. Nature 461:976-979. https://doi.org/10. 1038/nature08465

45. French E, Bollmann A (2015) Freshwater ammonia-oxidizing archaea retain amoA mRNA and 16S rRNA during ammonia starvation. Life 5:1396-1404. https://doi.org/10.3390/life5021396

46. Sorokin DY, Tourova TP, Kolganova TV, et al. (2002) Thioalkalispira microaerophila gen. Nov., sp. nov., a novel lithoautotrophic, sulfur-oxidizing bacterium from a soda lake. Int J Syst Evol Microbiol 52:2175-2182. https://doi.org/10.1099/ijs.0. 02339-0

47. Inagaki F, Takai K, Nealson KH, Horikoshi K (2004) Sulfurovum lithotrophicum gen. Nov., sp. nov., a novel sulfur-oxidizing chemolithoautotroph within the $\varepsilon$-Proteobacteria isolated from Okinawa Trough hydrothermal sediments. Int J Syst Evol Microbiol 54:1477-1482. https://doi.org/10.1099/ijs.0.03042-0

48. Xiang X, Wang R, Wang H, et al. (2017) Distribution of Bathyarchaeota communities across different terrestrial settings and their potential ecological functions. Sci Rep 7:45028. https:// doi.org/10.1038/srep45028 
49. Stieglmeier M, Alves RJE, Schleper C (2014) The phylum thaumarchaeota. In: Rosenberg E, De Long E, Lory S, et al (eds) The prokaryotes. pp 347-362

50. Xu Y, He Y, Tang X, Brookes PC, Xu J (2017) Reconstruction of microbial community structures as evidences for soil redox coupled reductive dechlorination of PCP in a mangrove soil. Sci Total Environ 596-597:147-157. https://doi.org/10.1016/j.scitotenv. 2017.04.073

51. Spang A, Saw JH, Jørgensen SL, et al. (2015) Complex archaea that bridge the gap between prokaryotes and eukaryotes. Nature 521: 173-179. https://doi.org/10.1038/nature14447

52. Inagaki F, Nunoura T, Nakagawa S, et al. (2006) Biogeographical distribution and diversity of microbes in methane hydrate-bearing deep marine sediments on the Pacific Ocean margin. Proc Natl Acad Sci USA 103:2815-2820. https://doi.org/10.1073/pnas. 0511033103

53. Andreote FD, Jiménez DJ, Chaves D, et al. (2012) The microbiome of Brazilian mangrove sediments as revealed by metagenomics. PLoS One 7:e38600. https://doi.org/10.1371/journal.pone.0038600

54. Oren A (2014) The family Xanthobacteraceae. In: Rosenberg E, De Long E, Lory S, et al. (eds) The prokaryotes. Springer, Berlin Heidelberg, pp. 709-726

55. Alongi DM (2005) Mangrove-microbe-soil relations. In: Kristensen E, Haese RR, Kostka JE (eds) Interactions between macro- and microorganisms in marine sediments. pp 85-103
56. Reysenbach AL (2015) Thermoplasmatales ord. nov. In: Whitman WB (ed) Bergey's Man. Syst. Archaea Bact. John Wiley \& Sons, Inc. https://doi.org/10.1002/9781118960608.obm00055

57. Otero XL, Lucheta AR, Ferreira TO, et al. (2014) Archaeal diversity and the extent of iron and manganese pyritization in sediments from a tropical mangrove creek (Cardoso Island, Brazil). Estuar Coast Shelf Sci 146:1-13. https://doi. org/10.1016/j.ecss.2014.05.002

58. Rey JR, Carlson DB, Brockmeyer Jr RE (2012) Coastal wetland management in Florida: environmental concerns and human health. Wetl Ecol Manag 20:197-211. https://doi.org/10.1007/s11273-0119235-1

59. Stringer CE, Rains MC, Kruse S, Whigham D (2010) Controls on water levels and salinity in a barrier island mangrove, Indian River Lagoon, Florida. Wetlands 30:725-734. https://doi.org/10.1007/ s13157-010-0072-4

60. Portnoy JW, Giblin AE (1997) Effects of historic tidal restrictions on salt marsh sediment chemistry. Biogeochemistry 36:275-303. https://doi.org/10.1023/A:1005715520988

61. Brockmeyer RE, Rey JR, Virnstein RW, et al. (1996) Rehabilitation of impounded estuarine wetlands by hydrologic reconnection to the Indian River Lagoon, Florida (USA). Wetl Ecol Manag 4:93-109. https://doi.org/10.1007/BF01876231 